\title{
The Role of the Injured Party in Compensation in International Law
}

\author{
Hassan kouzehgar \\ Department of Public and International law, Science and Research Branch, Islamic Azad University, Tehran, Iran \\ Corresponding Author \\ Mohsen Vaseghi
}

Department of law, Payame Noor University (PNU), PO BOX 19395-3697, Tehran, Iran

\section{Doi:10.5901/mjss.2015.v6n6s6p375}

\section{Abstract}

This article seeks to examine the role of damaged in compensation in international law by using descriptive analysis. The findings suggest the Roman law, on the assumption that the offender commits a crime, he was excluded from receiving any kind of damage, without the type and extent of his involvement in the investigation of the loss. In the old system there was no common law as well.But gradually, the rule of law amended particularly in the common law. International Convention determined the manner of assessment of loss on the basis of new transaction replaced the violated transaction. The victim of the violation, by the seller or the buyer, he can terminate the transaction price difference between primary and alternative assumptions or purchase contract to receive compensation that is applied to alternative transaction.

Keywords: damaged, loss, international law, international conventions of goods, common Law legal system

\section{Introduction}

One of the most important issues in the law of civil liability is to investigate the role of the injured in the loss and its impact on the civil liability of losses. The problem is to investigate effect the loss of civil liability when the injured in the loss which he has been involved, or fault, and his fault in the event of damage to be effective. Whether this leads to a complete denial of compensation or under the division of responsibilities and the amount of damages that he should receive reduced.

This issue has long history in the common law, and the doctrine of "common fault is investigated as a defense from civil liability claim arises read. Although, in France Law, the issue is discussed as "General fault, but developments in this regard in the common law system have been considerable, and to be aware of the historical background of this rule and its developments must be presented to the legal system. Under common law, the mid-twentieth century, the subject of analysis and division of responsibilities, was not accepted by the courts. For this reason, according to the traditional principle of "common fault" losses seen that his fault was effective in the event of loss, was excluded from receiving any damage. Over the centuries, many criticisms were based on the rule of law and the courts tried to invoke the theory part of this rule is to reduce violence and hardship. Evaluation of this evolution and the conditions for the implementation of this rule existed at common law system, the historical and comparative study is worthy of reflection.

In addition to the mentioned legal systems, the Convention on the International Sale of Goods Act 1980 explored the legal document advances in the field of international sales at 74 to a 77 , the main issues for damages arising from a breach of contractual obligations.

Demanding the compensation is the most applicable guarantee for implementation and contain most technical legal issues in the Convention on the International Sale of Goods. The victim of the violation has the right to demand the loss (either seller or buyer). Unless accordance with Article 79 of the Convention, performance becomes impossible (e.g. force majeure). In addition, it is possible to demand the loss simulant with other methods of compensation caused by violation of breach.

Article 74 of the Convention which is the main material compensation, first, it refers that in the first sentence to damage resulting from breach of contract, including material damage and loss of profit mentioned and more elements of the responsibility to fulfill the contract and claim damages. Moreover, Article 74 contains the basic rule concerning compensation for all the damages caused by the violation was known as the necessary compensation. Note that all 
damages arising from breach of contract, including material damage and loss of profit must be compensated. Whereby the injured party of a breach of the economy and the full implementation of the agreement will be without flaws. This research is to investigate the role of the injured party in compensation under international law. Accordingly, the history of the issue will be presented, the victim in the legal fault conditions in the international rights and the role of the injured party in compensation explained and described in the Convention on the International Sale of Goods.

\section{The first Issue- the history and role of the injured party in the compensation rules in international law}

In order to understand properly the fault responsible injured on reparations in international law must first be subject to a separate history - the Roman law and common law legal systems and systems La-reviewed literature and the role of damaged goods in the International Covenant as one of the most important conventions of international law will be explained and described.

\section{The first speech- written Roman law and legal systems}

Injured in Roman law that was suffered by his fault, but if the fault was intentional fault of the type of injury suffered, the claim for compensation was denied. According to Pomponius, loss caused by one's own fault is not be considered loss. A set of civil law of the old Rome developed "inflicting severe damage on fault" to reduce the harsh impact of this rule. According to this rule, the party who is less blame can go to someone who is bigger fault. Apart from some countries, such as Denmark that rule Pomponius abandoned and losses based on considerations of equity division was established, most legal systems without code, this rule were maintained. While in countries with written law, due to be launched to coincide with the industrial development of Western law codes, or after it, and because the dominant codes were relying on the theory of fault, naturally accepted the principle of the division of damage. Because this rule is only possible mechanism to consider "the reality of fault on the part of both sides". In the case of countries with written law on the subject can be said that in some of these countries, such as Austria, Sweden and Germany the legislator has stipulated the possibility of sharing and distribution losses and in some other countries such as France, precedent to this conclusion. Moreover, even in countries that apparently have agreed to follow the Roman law: "The action is due to fault attributable to the injured, the source of the damage to his responsibility for not looking", as well as, in practice, jurisprudence, law to cases of intentional fault of the injured have been limited. Of course, some countries have maintained Pomponius rule in the case of an injury suffered or assumed responsibility for operating and in other cases they have left.

\section{Second Speech- Common Law Systems}

In the early nineteenth century, English law with the rule of "participating in error" achieved the same result as Pomponius rule without necessarily imitating of the rule. However, in the law of the country in error, except in hypothetical claim by the injured prohibit the entry of the losses have deliberately set out to create it. Although the courts for relief measures quickly speculated this rule (as a rule reveal one last chance to avoid losses), the underlying principle Vote losses (and not its negation) must be documented in a special law expressly stipulates that be. In some Commonwealth countries, reforming legislation in issue has been established, the losses when the fault, sometimes the degree of influence (participation in the cause), and sometimes justice is sometimes a combination of these criteria. Also, in addition to the theory of "participating in error," the common law system, implies another rule that is considered independent of the above rule and provides that the injured should minimize losses. While other legal systems failed to reduce (minimize) the fault of the injured is considered a loss. The third issue is the role of the injured party in terms of the impact of compensation. For the injured, the responsibility of operating loss to be effective, there must be circumstances;

\section{First Paragraph - the Fault of the Injured}

In the common law system of Western countries blame the injured, the condition of the effect of his actions on the responsibility of operating losses and he must prove it. As a rule of common fault can understand the need for this requirement. The reason is clear, because the legal system "fault" is the responsibility and liability of fault although exceptions are accepted, but because it has been established to support the injured, talk about the injured and the 
responsible one (injured) does not apply. But in spite of this provision, the concept of "fault injured" (to themselves), and that the fault of losses (to another) should be evaluated. There is serious disagreement and debate. Some writers made it clear that they do not need to "blame the injured" in the sense of its own fault-based civil liability, but also equally to the injured and the mindless reckless than he is, is enough.

\section{The Second Paragraph-Causal Relationship between the Injured and the Damage Caused}

A basic condition for the effect of the loss of the injured on civil liability is that there is a causal relationship between his actions and the harm caused.

The base of this condition is what has the pubic meaning in civil liability.

Because the basic condition for the establishment of civil liability is the causal relationship and this is a rational rule there is no need for giving reason. In

Ram bray law enforcement, "rule of common fault", the causal relationship was the main condition. Common law system, what in the past that the rule of "common fault" completely deprived the injured and compensation, what now that may reduce the damages of causal relationship between the basic conditions. The third paragraph of the injured, caused by the action of an agent is not. The effect of the condition of the injured, is that his action has been taken under the influence of loss and is not caused by it. In other words, fault or risk the loss of causes and dynamic action (or failure) is not injured. When a person due to his fault or action, another puts in a dangerous situation, and he attempted to escape danger, but in the end not only his actions would not risk his freedom, but also injury suffered by him and proved that if he did not, indeed he would not hurt.

\section{The third Issue-the Role of the Injured Party in Compensation in International Convention of the Goods}

General principle of international commodity Convention in this regard is that any damage, including damage caused by breach of contract should be compensated, victim of breach of contract, as far as possible should be under full implementation and proper contract. In other words, the damage must be completely sharp. But it requires compensation, terms, and calendar of the injured and assess the damage amount of money that it received the expected benefits and pledged to crush legitimate and comes from performance of the contract provided. But the formulas and methods for evaluating damage in Articles 75 and 76 of the Convention stated that its application is based on breach of contract committed (either seller or buyer) and with crushing committed breach of contract by the loss of the breach of contract. For example, the seller refused to surrender the goods or goods delivery is fundamentally flawed and that the buyer declares termination of the contract, or by other buyers to bill goods and pay the price, not the seller declares termination of the contract. Now, if the damaged by the breach of contract, with subsequent cancellation, resorted to the transaction to be replaced, the difference in the initial transaction price and transaction alternatives, as well as all costs and expenses incurred in order to do so, provided they meet the provisions of Article 75, will demand Closed. If the injured party to terminate the agreement under Article 75 to deal, but not replace, the price difference of the termination of its contract with the current price of goods on the market at the moment and terminated with a bill of goods (whichever happens first) as damages to be charged. If it is not offset losses by applying the above article, Article 74 of the general formula and the initial compensation, it will be responsible.

\section{The First Speech- The Alternative Transaction by the Damaged}

Damage assessment is documented based on the realization of the so-called alternative transaction or objective assessment of the actual compensation and the basis of Article 75 of the Convention.

According to the article, "If the contract is terminated and the customer after notice of termination to the conventional manner and within the time standard, goods sold things other than the object of sale to another seller bought or sold, the party claiming damages, can these price differences The contract price of the transaction will require replacement. The reason for naming this method is the method of objective assessment of damages based on the fact that an alternative transaction that achieved identified and evaluated. Therefore, what is important and evaluation criteria is implementation of an alternative transaction to the conventional manner and within a reasonable time after notice of termination of the contract. In other words the realization of the transaction referred to in Article 75 is replaced by the requirement to apply the rules. The mere possibility of an alternative transaction and not realize it is not sufficient for this article. The aim and purpose of Article 75 of the Convention is the provision of primary interest and commitment in favor 
of the execution of the contract and what is certain as the expected benefits to be identified.

In the case of non-performance of contracts by committed, if your crush is committed to serve the interests of his contract, the rules of fair compensation to him. He also supported. Accordingly, in the event of early contract termination and replacement by a pledge in favor of the transaction, based on conventional methods, he can be expected to damage done to him on the basis of an alternative transaction, evaluated and compensated. This assumption is true about the buyer and seller. If the injured party is the buyer for breach of contract, he is entitled to the difference between the original purchase price and replacement transaction if the price was higher than the price of the initial contract, is entitled to receive.

On the other hand, if the seller is a victim of a breach of contract, he is entitled to the difference between the original contract price and the substitute transaction in the form of lower transaction cost to replace the original transaction as the damage claim. Or a real and objective assessment based on Article 75 of the Convention, to assess subjective and based on Article 76 i.e. on the basis of the market price prior to the transaction, assuming fulfillment of the conditions set forth in Article 75 of replacement, citing the possibility of resorting to Article 76 if it is insignificant Implementation of Article 76 had committed more beneficial and useful to be crushed.

Basically, applying the procedure set out in Article 75 and transaction alternatives, costs and expenses referred to in Article 76 in its lower surface and is often more useful and beneficial had committed will be crushed are crushed because they, more than anyone else, envy and self-interest was created to observe. However, if you are in favor of alternative provisions and conditions set forth in Article 75 of the Convention deal does not meet, no longer mentioned in Article 75 to assess the damage to their quality of adultery.Note that crushed commitment as a legal obligation to deal with the issue of compensation for damages as set forth in article 77 of the Convention deal with and if it does not fulfill its duty, sanction the use of Article 75 of the exclusion.

\section{The Second Speech- The Alternative Transaction by the Damaged in Conventional Methods}

As noted above, an alternative transaction are expected to provide benefits in favor of the execution of the contract is done, this should be done through conventional or reasonable. This applies to the seller (victim of a breach of contract), please substitute the highest possible price and the buyer (victim of a breach of contract) Order replaces the lowest possible price.

However, to prove the transaction conventional alternatives, it should have all the characteristics and conditions of the transaction consideration, cash payment, guarantee conditions, conditions related to the transportation of goods, packaging and other additional facilities or under alternative contract.

Buyers who do not deliver goods purchased at an alternative transaction, it can in order to maintain the credibility of its business and meet its obligations to customers of the products in the warehouse, which has already been obtained, and the type or similar goods bought at bargain alternative, deliver to our customers; but the price or cost of replacement is required to the account of the seller (violation).

It is not necessary for the realization of an alternative transaction injured party has already declared this to be his opponent. However, with one of the proofs he can be recognized. The victim of a breach of contract replacement deal can do exclusively or at auction, limitations governing the assessment of damage, replacing the need for conventional transactions, referred to in Article 75 of the Convention.

Convention victim did not have to do an alternative transaction, but he is empowered to do so. However, if the omission victim, violation of the general duty to deal with the damage seen, especially in a supposed victim of the breach, Buyer and rising market prices. This will be of assessing damage to him. It means that to the extent of losses that could have been avoided, the other will not be charged.

\section{The First Paragraph-Diagnostic Methods of Alternative Transaction}

One of the ways of identifying an alternative transaction (sale or purchase) is its notification obligation or crushed (victim of the violation). In this case, he who following the initial contract and its termination notice, declared its intent to sell or buy a replacement to the opposite side. Such assignment shall explicitly committed not crush load, but it could be something on the basis of Article 9 of the Convention and according to the common law and common business practices between the parties, including the principle of good faith concluded. In most cases, buying or selling replacement of the existing evidence is recognizable. However, assumptions that are crushed and continuous professional trader to buy or sell goods in question was created, the diagnosis is not possible to ease the difficulties. In the event of a dispute over the 
recognition of an alternative transaction, committed Crush (victim of violation) should be fixed, in each case which of buying or selling, an alternative transaction that was done to ensure the interests of his contract. Therefore, in terms of the burden of proof in favor of the pre-committed to the interests of its intention to deal with a possible alternative to specify it.

\section{The Second Paragraph- the Necessary Conditions for the Realization of an Alternative Transaction}

\subsection{The necessity of Termination}

According to Article 75 of the Convention, it is necessary to terminate the initial contract was violated by the obligation, to buy or sell quote and then replace happen. In other words, an alternative transaction occurs following the termination of the initial contract. However, the existence of alternative applies when the initial contract would be neutralized. As a general rule, the termination of the contract is that it reveals the lack of enforcement. Terminate the contract makes the parties' contractual rights and obligations, particularly with regard to ownership of the goods to be and gives them the freedom to sell or buy a replacement, when the contract is not terminated, it should be done;

Even breach of contract by one side, the other does not have the right to perform alternative transaction frees itself from the principal obligation; unless the victim of the violation, primarily by giving notice of termination, the contract is terminated. Convention dissolution or termination of the contract itself has recognized. Therefore, notice of termination is inevitable. This requirement is an important exception and that is where the commitment is definite and irreversible breach of his contract; so that at the time of the transaction is indisputable that the alternative would not commit to its obligation, the right to demand performance of the contract is also committed to not crush. In this case, there is no need for a cancellation notice. But the transaction is committed replaced by crushed implicitly replaced reason to terminate the contract early would be considered.According to Article 25 of the Convention, which provides that:

"When fundamental breach of contract by one party, which could have resulted in lots of damages to the other party so that is what he is entitled to expect under the contract, basically deprived.When committed explicitly and irreversible breach of the area concerned or acts that indicate a breach of contract, on the basis of a pledge in favor of the right to speak or act committed, to terminate the contract.Lehigh committed to terminate the contract, it will not have the right to request the obligations can only be based on the transaction's alternative claim for damages.

\subsection{The Conventional of the Date of the Alternative Transaction}

Victim of a breach of contract shall alternative transaction within reasonable time after the termination of the contract, allowing in accordance with Article 75 to calculate the damage to its own.

The exact time of termination of the contract is highly important. As of this date, the standard time is calculated. Conventional transaction and the length of time it is something relative and depends on the particular circumstances of each case. If the product is high potential sale or liquidity, it is expected to spend less time in emergency or alternative transaction goes. As in cases where the goods supplied in exchange transactions and the price is fixed. In any case, the Convention on Conventional diagnosis of alternative transactions or urgency, no specific criteria and that the custom and practice in certain goods trading will leave.

\section{Conclusion}

Injured effect on operating loss responsibility, under international law as far as legal system is Roman and common law have seen many developments. The basis of this principle that the rights of the common law system reached Rome, it was not possible to analyze the division of responsibilities accepted. That's why even later that the theory of "Last Chance" was launched, Full impose losses on operating result was loss and guilt injured were ignored. In other words, the solution "either all or nothing" was implemented, or fully compensate the injured was deprived to receive any type of compensation.

This situation continued until the second half of the twentieth century until the theory of "division of responsibility" was accepted and in 1945 adopted a law English law and the rights of America precedent theory of "comparative fault raised. If the effect of the injured on the responsibility of operating losses, in addition to the causal relationship, that does not intentionally cause harm his actions caused the driver is not injured. Unlike in Western legal systems, in Islam and Iran, the impact of his actions on the authority of an agent is not the fault of the injured condition. As we have seen, the 
Convention on the International Sale of Goods, the discretionary powers granted to the victim of a breach of contract to deal with alternative and charge different prices and costs and expenses, in the ideal situation and expectations of the implementation of the initial contract their legitimate performance of the contract is required.

This authority is not absolute and subject to observance of the transaction conventional alternatives in terms of how and when to do it. Failure to observe the condition of the victim to claim damages on the basis of an alternative transaction, and launches not only entitled to damages based on the prevailing price of the commodity on the market. Although he has not replaced the injured party mainly engage in the transaction.

The above provisions apply subject to early termination of the contract with the victim, If by applying Articles 75 and 76, part of the losses arising from breach of contract remain uncompensated, Article 74 of the Convention to make up for its shortcomings covers the gap. In jurisprudence and legal systems of most of the legislators and legal authors on the damage assessment is focused on the rules of civil liability out of contract "liability violent" discussions, particularly seizure, loss and causality, and on the responsibility of the contractor under the project have been considered separately.

\section{References}

A.M. Honore, Torts-Causation and Remoteness of Damage, International

Encyclopedia of Comparative Law, V.XI, Ch.7, Oceana Publication Inc., New York, 1791, p.49, No. 541.

Anson, the Law of Contract, Oxford, 1998, p. 648

Bridge, Michael, The international Sale of Goods, Law and Practice, Oxford, 1999, p. 158

Enderlein Fritz \& Makow Dietrich, International Sales Law (UN Convention on Convention for the International Sale of Goods), Oceana Publications, New York, London, Rome, 1992, p.299

Faute de la victim; Cf. Mazeaud)H.L.et J.(,Locons de droit civil, Tome II,Paris,9591,n 195 et seq; Mazeaud et Tunc, Traite theorique et pratique de la responsibilite civile, Tome I,6e ed.,Paris,5691,n 0541 et seq

Fleming, The Law of Torts, 3 ed edition, Sydney, Melbourne and Brisbane, 5691, p. 322 et seq.

Honnold, John O. Uniform Law For International Sales Under the 1980 United Nations Convention, Kluwer Law and Taxation Publisher, Deventer-Boston, 1991, p. 321

Marty et Raynaud, Droit civil, V.II, Paris, 2691, nos 794

Mazeaud ET Tunc, Op. Cit, n. 1505

Neumayer, karl, H. Ming catherine, Convention de vienne sur les contracts de vent international, (24th ed), CEDIAC, 1995. p. 158

Neumayer, karl, H. Ming catherine, Convention de vienne sur les contracts de vent international, (24 th ed), CEDIAC, 1995. P. 321

Schleehtrim, Peter, Commentary on CISG, Translated By Geoffrey Thommas, Oxford, University Press, 1998. P. 553

Schleehtrim, Peter, Commentary on CISG, Translated By Geoffrey Thommas, Oxford, University Press, 1998. p. 553.

Treitel, G.H., Remedies for Breach of Contract. A Comparative Account, Clarendon Press. Oxford, 1989. P. 57

Treitel, G.H. The Law of Contract, Sweet \& Maxwell, London, 1995. p. 65

William L. Prosser, Hand book of the Law of Torts, Fourth edition, West Publishing co.,1791, p. 714 et seq. Fleming, The Law of Torts, 3 ed edition, Sydney, Melbourne and Brisbane, 5691, p. 322 et seq. 